\title{
Factoring Central Asia in the Russia-India Energy Trade
}

\author{
A. Dhaka, M. Dmitrieva \\ Jawaharlal Nehru University, India \\ Far Eastern Federal University, Russia
}

\begin{abstract}
The article looks into the Russia-India energy trade potential and its strategic significance with a particular focus on the Central Asian energy trade. Russia has become a major player in the energy market and its handling of Syrian crisis has enhanced its position in the Middle East that has impact on oil market and production scenario. India has been a growing at a rate of above $5 \%$ and its energy needs have been substantial. India and Russia share a very special relationship due to long-standing cultural and political ties and this has been a facilitator to India's energy security needs. The Central Asian Republics hold a special position for Russia and India in terms of strategic security across South and Central Asian region. The two countries not only deeply connect themselves with the region but also find it necessary to preserve the region from religious extremism and terrorism that is worsened by the narcotics and arms trade. The Central Asian republics are a house to some of the world's largest natural gas reserves and they have been exporting it large volumes through pipelines. However, the approach has not materialised as South Asia due to the Afghanistan situation. Therefore, Russia remains an important route to access energy resources from Eurasia and Central Asia in particular. India also has high exposure to the maritime energy trade with Africa and Latin America countries that contribute to the counting opportunity cost for accessing Central Asian energy. The paper highlights the significance of energy trade between Russia, India and Central Asian countries that could contribute to geopolitical stability across the region.
\end{abstract}

Keywords: Russia, India, Energy Trade, Central Asia, Afghanistan, South Asia, Geopolitics, International Cooperation, Strategic partnership

The energy security has been dealt by scholars both at the foreign policy level and also at the regional level identifying the economic organisation of regions and inter-regional networks. The year 2000 European Commission green paper on energy security outlined the challenges of energy supply with the expansion of the EU. The call for shifting energy relationship from bilateral framework to a multi-lateral or an inter-governmental institutional framework has competing perspectives both 
from the consumer and the supplier side. Russia has been reluctant to subscribe its energy interests under a global framework of energy trade such as Energy Charter Treaty and Kyoto Protocol (Belyi 2003). The neo-classical realist perspective can be applied to understand the policy choices outlined by Russia with its principal consumers. The institutional posture of the European nations encourages Russia to seek an alternative to a monopsony arrangement. And, to this effect Asia appears to be the most natural and lucrative destination for the supply of its energy products. The most notable consumers are China and India which have huge unsatiable demand for energy consumption. India also looks to unwind its energy priorities in a growing diverse market with a desire to reduce dependence on the Middle East suppliers as the region has always been a hotspot for the US sanctions and often a regional conflict upstaging the secure supply.

This paper looks into a particular dimension of the Russia-India economic relations with two variables. The first consideration is the energy trade and its sustainability as a proof of time-tested partnership between the two countries. Second, component is the possible capitalisation of this relationship to coordinate geopolitical interests in Central Asian region. Russia and India both consider stable and secure Central Asia vital to their interest as the potential dangers of extremist and violent tendencies have consequences for both the countries. Since, the Central Asian countries are rich in hydrocarbons, the Russia-India energy trade relations can always factor into the Central Asian energy resources as a part of their trade matrix. Energy relations reveal a kind of complex interdependence with consumer nations largely providers to energy technology and the consumer nations largely dependent upon such technological breakthroughs in order to enhance supplies of hydrocarbons. Thus, the hydrocarbon supplier states often are interested in attracting investments from the consumer states in refining and transport infrastructure for supplying resources. China represents a strong case where it has invested heavily in such technological and financial projects both in Central Asia and Russia. India, however, has been a modest partner of Russia and Central Asian republics in this regard. However, there is a multi-dimensional aspect of Russia-India relations that provide impetuous for forging a strategic energy partnership in the South and Central Asian region. This is also borne out by the fact that energy is one dimension of the multiple dimensions of security partnership. And, according to Copenhagen school, security can be comprehensive policy under a neoclassical framework with political stability, military capability, economic resourcefulness, environmental protection and technological sovereignty. Energy security definitely reveals a varying mix of these security concerns at different tiers of conventional to non-conventional energy security consideration. Just as Russia would try to adjust between its European and East Asian markets, the South Asian vector appears to be suave and humble in terms of geopolitical priorities. India and Russia offer each other much needed diversification amid the growing competition between the potential suppliers and the buyers. Central Asian countries too find themselves under the east-west predicament in terms of potential direction of supplies (Fredholm 2012). 
India does not have direct land route with Central Asian countries and its dependence for access is either through Russia, a strong military power. India as an aspiring global player attaches great importance and shares a special bond with Russia since the past century. Russia has influenced the minds and thoughts of Indian intelligentsia and so has been the vice versa. This paper also emphasizes the case of Russia-India energy trade as a stimulus to the Central Asian economies that are essentially smaller with a major focus on energy exports. This has a strategic dimension because of the Afghan neighbourhood. The politically stable and economically sound Central Asian statehood is vital for inducing positive influence on Afghanistan from the north. This contributes the geopolitical dividends to both Russia and India.

\section{Russia-India Energy Trade Relations}

Russia and India share a special relationship that has evolved much through the cold war history based on mutually recognized principles and common global interests. The desire to see a balanced world with non-hegemonic architecture for economic and political interests is the founding principle of a long-trusted friendship between the two nations. The relations have survived the test of times particularly in the aftermath of the dissolution of USSR, which followed by the structuring of Indian economy under the IMF-World Bank prescribed reforms snapped many pre-existing arrangements of trade and finance. The present state of Russia-India relations demonstrates the newly acquired pragmatism by both the countries with an adjustment to the post-cold war realities. However, it is ironical that despite a long-standing relationship, Russia and India do not trade much. The Russia-India trade volume does not reflect the kind of strong partnership both the nations enjoy (Minina, Glekov 2019). It misses the $18^{\text {th }}$ century legacy of strong economic ties that flourished between the Russian cities of Ufa, Astrakhan, and Orenburg with coastal towns of Gujrat or trade relations traversing through Gangetic plains up to Calcutta (Khusainova 2015).Some scholars point to the changed priorities of the Indian government in post-cold war period that has transformed the relationship from ideological to a more pragmatic one. The US gained importance in South Asia particularly after 9/11 and concomitantly the big powers made significant geopolitical adjustments. The US-India strategic partnership is a big change in the region. India has been a reluctant partner of the US in tackling China and at the same time, it has cautious approach towards growing dependence on the US for its military, nuclear, space and strategic programme (Garusova, Zhurbey 2018). It is also true that part of India's procurement of military supplies from Russia has shifted to the US arms industry in recent years (Zakharov 2016). The Russia-India arms trade is a narrow vision of the trade relations between the two countries. India and Russia are both big economies and there are numerous sectors where technology and product diversity remain unexploited.

Russia's trade orientation towards energy minerals is a consequence of the USled sanctions imposed in the aftermath of Crimean parliament voting to join Rus- 
sia in 2014 by an overwhelming majority; a democratic situation not acceptable to the West. This ordered a rethinking among the Russian policymakers to look towards Asian economies, which are as much burgeoning and robust as compared to the West. India, China, Northeast and the Southeast Asia offer a host of opportunity for Russia to expand its economic relations, which have been hitherto modest. Russia maintains a comparable trading volume with the US and India despite the fact that the US has a sanction regime against the Russian business. Its exports to both the countries were around 7.6 and 12.6 billion USD in 2018 respectively, while its imports were around 2.8 and 9.2 billion USD respectively. Similarly, Russia's trade with the ASEAN in 2018 was around 9 billion USD in exports and 8 billion USD in imports. Russia traded in high volumes with China measuring 56 billion USD in exports and 51 billion USD in imports in 2018. However, the strongest trading partner for Russia was the EU15 in 2018, which had a volume of 150 billion USD in exports and 75 billion USD in imports ${ }^{1}$. This reveals that Russia has a strong continental trading regime spreading to the east and the west. It also signifies that the continental trade is relatively free from sanctions in comparison to the maritime trade. One of the important indicators of Russia-India trade situation is the lack of interest from the Indian partners into Russian business environment. There are gaps in sharing the business knowledge between the two countries and there is higher geographical opportunity cost that factor into overall trade potential. This also contributes to the scenario, where Russia-India-China trade potential remains deeply under-developed as far as their engagement under the BRICS framework is concerned (Guchmazova 2017). Over more than half of Russia's exports comprise of the energy minerals such as, petroleum crude, their distillates and natural gas, both gaseous and liquefied. The unclassified commodities under the Harmonised System of commodity classification accounts for second largest export group amounting to $14 \%$ of its export share ${ }^{2}$. If one looks at Russia's energy mineral trade with India and China (Table 1), then it shows strong continentalism.

Table 1.Russia's hydrocarbon exports

\begin{tabular}{|c|c|c|}
\hline Year & Share of India (\%) & Share of China (\%) \\
\hline 2009 & 0.26 & 4.99 \\
\hline 2010 & 0.15 & 4.85 \\
\hline 2011 & 0.1 & 8.07 \\
\hline 2012 & 0.06 & 8.17 \\
\hline 2013 & 0.06 & 8.34 \\
\hline 2014 & 0.08 & 9.61 \\
\hline 2015 & 0.18 & 10.97 \\
\hline 2016 & 0.31 & 13.16 \\
\hline 2017 & 0.88 & 14.74 \\
\hline 2018 & 0.79 & 17.55 \\
\hline
\end{tabular}

Source: UNComtrade.org

\footnotetext{
1 Merchandise Trade indicators, annual, 1995-2018. UNCTAD. URL: http://unctadstat.unctad.org/wds. ReportFolders/ reportFolders.aspx (accessed 21.12.2020)

2 United Nations commodity trade statistics database. URL: http://comtrade.un.org
} 
The Russian and Indian trade policies are protective in nature that act as obstacle in expansion of trading volumes. Russia's reliance on exports of primary goods has restricted its participation in global value chains. It has been inviting investments for harnessing its vast natural wealth, but sanctions have deterred from the further opening of economy. The Russian economic structure is more in accordance to its engagement with the EU countries (Sutyrin, Trofimenko, Koval 2019). Just as Russia needs investments for exploiting its vast natural resources, India too needs investments into its economy with huge pool of skilled work force. Therefore, India and Russia need to innovate their economic cooperation where the long-term complementariness can grow between the two. Both, India and Russia need to be part of multi-lateral trade regime that can work across geographical barriers. This paper aims at looking into the Russia-India energy trade potential as a geopolitical insurance to the Central Asian republics who are in neighbourhood of Afghanistan. Energy trade has a strategic value for landlocked countries and its use as an incentive to manage security challenge has been a common meeting ground for Russia-India strategic policies.

If we look into India's exports to Russia then it represents a significant legacy of colonial times when the British were keen to export tea, cotton and spices via Central Asia. The present scenario is no different as coffee, tea, mate and spices still constitute a major share of India's exports to Russia as of 2016-17 (Konovalova 2017). Petroleum imports constitute nearly one third of the total India's imports followed by precious stones and metals. The nuclear energy and electrical machinery is the next big segment of imports. Russia figures well in last three sectors but there are very little imports of energy minerals from Russia. India's energy imports share in Russian energy exports is less than one percent, while China's imports have grown steadily. China imports nearly 18 percent of Russian exports of energy minerals. This indicates the strong geopolitical barrier in the form of destabilised Af-Pak region, which prevents any smooth contact between Russia and India via land route. This is in addition to the immense geographical barrier of Hindukush Mountains, which straddle in the heart of Afghanistan. Central Asia's vulnerability to the situation in Afghanistan affects both Russia and India in a significant manner. This highlights the growing need for a common understanding on the fight against religious extremism and narco-terrorism, and finally, both Russia and India expect a multi-polar world system that is free from any hegemony of economic coercion and protectionist tendencies. The opportunity to trade and economic development on fairer terms are the global objectives of Russia-India partnership (Akarashov 2017).

Russia and India have made promising start in oil refining business based on oilfields in Russia's Far Eastern Region. India received the cheapest LNG shipment under the long-term deal agreed by Russia's Gazprom and India's Petronet LNG for shipping $\$ 25$ billion worth of gas. The Dahej terminal received the shipment at \$1-1.5 per mBTU cheaper than Qatar, Australia and the US ${ }^{3}$. The Kochi terminal is also operated

\footnotetext{
3 India gets cheapest LNG as Russia's Gazprom begins supplies. The Hindu. URL: https://www.thehindu.com/business/ Industry/india-gets-cheapest-Ing-as-russias-gazprom-begins-supplies/article24080583.ece (accessed 21.12.2020)
} 
by Petronet, while several Public Sector Units (PSUs) are operating other terminals such as Dabhol, Ennore, Chara etc. Several Private terminals are also coming up such as Adanis building Mundhra and Dhamra, Royal Dutch Shell operating Hazira, while Kolkatta/Dihga being built by H-Energy Global. In fact, H-Energy Global and Russia's Novatek signed long-term agreement for supplying to end-users in India and Bangladesh. Novatek has also signed MoU with Petronet for supplying LNG to electricity plants. The Russian shipping giant Sovcomflot will be delivering LNG for Novatek projects including from the Arctic LNG-2 (Griffin 2019). India has total LNG terminal capacity of 71.5 MMTPA according to Petronet.com. Russia and India can further expand cooperation with both public and private enterprises joining in shipping and piping LNGs to several towns and cities across the country. The problem arises when there is pricing and commission disputes between multiple partners in project. A case for instance was noted when the US origin LNG cargo was not allowed to be alighted at Mundhra port because of the dispute between Adanis and Gujrat State Petroleum Corporation (GSPC) ${ }^{4}$.

India is essentially a modest partner in Russia's Far East energy resources business, whereas the Chinese and European business have major stakes in many rich regions. This points to geographical factors as India is much closer to Iran, and Gulf nations who have vast resources of energy that is much cheaper to transport and even can be piped up to the Indian subcontinent. The huge gas discoveries in Bay of Bengal such as the Shwe project on offshore Myanmar and Bibiyana in Bangladesh also compete with the lucrativeness of Russian or the Central Asian gas (Dinakar 2020). This is important when the oil pricing is subject to geopolitical pressures that invariably bring down the crude prices making transportation an important component for the pricing of oil and gas supplies. The downward pressure on oil prices can be dealt with Indian investments in Russian refining business increases. This allows the export of higher value products from refinery points to consumer points at a much lower price. The Indian firms have committed more than $\$ 10$ billion investments in Sakhalin-1, TassYuryakh and Vankorneft fields for exploration and production. The Indian companies Bharat Petroleum, Indian Oil and ONGC are working with Rosneft for expanding business ties in this region. The ONGC Videsh Limited has 20 percent stake in Sakhalin-1 group of fields. Russia has invited India to its Vostok project for exploitation of the Vankor group of fields (Vankor, Suzun, Tagul and Lodochnoe fields), and field in Payakha, West-Irkinsky and Krasnoyarsk region ${ }^{5}$. The October Vladivostok Summit in 2019 focussed on number of energy ties that are possible between Russia and India. India showed keenness of LNG imports from the Russia's Arctic region and there is

\footnotetext{
4 Mundra LNG Project: Mundra LNG terminal to be commissioned by December. The Economic Times. URL: https:// economictimes.indiatimes.com/industry/energy/oil-gas/mundra-Ing-terminal-to-be-commissioned-by-december/ articleshow/71575407.cms (accessed 21.12.2020)

${ }_{5}$ India signs pact expressing interest in taking stake in Far East Russian oilfields. The Economic Times. URL: https:// economictimes.indiatimes.com/industry/energy/oil-gas/india-signs-pact-expressing-interest-in-taking-stake-in-fareast-russian-oilfields/articleshow/71171981.cms (accessed 21.12.2020)
} 
also scope of importing high quality coking coal. The Sakhalin-2 has major share of Gazprom, which is mainly devoted to LNG exports. The other 2 projects of Yamal LNG and Arctic LNG-2 are also important source of Russia's exports of LNG. The February 2020 also saw another agreement signed for the supply of crude from the Novorossiysk port of Russia to India. The Indian Oil Corporation (IOC) will receive nearly 2 million tonnes of oil from the Rosneft.

Perhaps the most sustained cooperation between India and Russia has been in the field of nuclear energy power generation. The Kudankulam is an epitome of Russia-India trust in the field of nuclear energy cooperation. However, it had its share of ordeal too when Russia's rivals stoked up public unrest in 2011 against establishment of unit 3 and 4, which caused resetting of India-Russia nuclear cooperation in the light of Russia’s constraints under NSG and India's risk liability rules (Parashar 2011). The project has become one of showcase of successful cooperation between Russia's Rosatom and India's Nuclear Power Corporation of India. The equipment and technology is being efficiently handled by the two companies. A serious concern had arisen in November 2019 as Russia-India rivals launched vociferous cyber attack that brought the two nations to setup a working group against such criminal attack ${ }^{6}$. Russia is keen to further enhance cooperation for second stage after having successfully completed 1-6 units of stage one of Kudankulam. Russia is increasing its footprint in Central Asian demand for nuclear energy. The experience of Kudankulam could be said to have provided rich experience in constructing the VVER-1200 reactors as the same are being planned by Rosatom together with Uzatom in Uzbekistan in Farishsky district near lake Tuzkan. India and Russia can forge a sustainable partnership with Central Asian republics who are rich in uranium for harnessing nuclear energy.

\section{Central Asia in Russia-India Relations}

The Central Asia figures as high priority in Russia's growing energy trade with the EU and East Asia. The first hypothesis looks into possibility of this expansion southwards towards the South Asian region. Moreover, the second investigation looks for the broader spectrum of relations with Central Asia that can be supported by the energy trade. Central Asia represents a strong range of geopolitical preferences for Russia and India. The India-Central Asia Business Council (ICABC) was launched in February 2020 with the aim of boosting trade. India's trade with Central Asia is low as two billion dollars. India approached Central Asia through its 'Connect Central Asia' policy in 2012 as a determined effort to maintain strategic depth beyond South Asia. It aimed at projecting India's soft power by investing in the sectors of education, medicine, information technology, telemedicine, tourism, joint scientific research and

\footnotetext{
6 Kudankulam nuclear plant is safe, India tells Russia. The Hindu. URL: https://www.thehindu.com/news/national/ kudankulam-nuclear-plant-is-safe-india-tells-russia/article29957732.ece (accessed 21.12.2020)
} 
security issues ${ }^{7}$. It was launched in 2012 in the wake of growing concerns about the situation in Afghanistan, which is a common concern for Central Asian countries and India. The first meeting of India-Central Asia foreign ministers was held in January 2019 in Samarkand, Uzbekistan, which was successive to the head of the state's meeting held in Astana in March 2018. It focussed on the industry-specific business forums and outlining means to establish sustained development of economic and cultural ties. It also welcomed India's inclusion in the Ashgabat agreement which can integrate with the existing international north-south transport corridor (INSTC) promoted by Russia and India. The two countries and Central Asian republics can greatly benefit from the expansion of trade under these schemes, which depend essentially on Iran for connectivity (Akarashov 2018). The INSTC has geoeconomic significance for Russia and India, and a vital strategic corridor to maintain regional balance in South and Central Asia, and the Caucasus. Many scholars are tempted to juxtapose this scheme with China's east-west run of transport lines under its Belt and Road Initiative (BRI). In the longer run, the east-west and the north-south transport corridors would complement each other for greater economic synergies. The various connectivity projects are the essence of the Great Silk road that traversed through the region since times anon. However, is affected by two regional factors. Firstly, the situation in Afghanistan and second, the India-Pakistan tensions, both of them have contributed to the killing of the Central Asian dream of reaching out to South Asia, which was so natural and so historical to the Asian people's heritage. Tolipov calls for the restoration of the dream that can disengage the region from its geopolitical chimera and transform the semiotics into substantial linkages (Tolipov 2015).

The Central Asian regimes have a unique dimension in the Russia-India engagement with the region. Russia's relations with these countries has treaded over a thin ice with tough bargain by these regimes. Uzbekistan's parliament approved to be the part of Eurasian Economic Union (EAEU) in April 2020. The question of joining was debated on the parallels of compromising Uzbek sovereignty. The growing demand for labour in Russia has been an important factor for Central Asian states in deciding on the membership of EAEU ${ }^{8}$. Russia finds the response of Central Asian republics contributing to the dialectical engagement at two different scales. Russia views the region keeping in mind the NATO presence in Afghanistan and the cold war legacy that could reignite trouble at any time. On the regional scale, Central Asia is a co-pivot to the Greater Central Asian region, which is a US policy paradigm that strongly links South Asia with post-Soviet Central Asia (Iazmuradov 2006). These trans-scalar geopolitics point India and Afghanistan as important concerns for Russia’s Central Asia policy. India's engagement in Central Asia is strongly encouraged by Russia and it assures

\footnotetext{
7 India says Iran frees 9 crew from seized Panama-flagged tanker. Retrieved from India says Iran frees 9 crew from seized Panama-flagged tanker: https://www.aljazeera.com/news/2019/07/india-iran-frees-crew-seized-panama-flaggedtanker-190726093040755.html

8 Hashimova U. 2020. Uzbek Parliament Approves EAEU Observer Status. The Diplomat. URL: https://thediplomat. com/2020/05/uzbek-parliament-approves-eaeu-observer-status (accessed 21.12.2020)
} 
curbing of security threats that are emerging from Afghanistan. On a trans-regional scale, it allows Russia to escape the binary of Russia-China competition in the Central Asian region.

The five Central Asian republics are in full consonance with Russian position as they feel there is a need to balance the growing Chinese influence in the region. The most significant aspect of Indian engagement in Central Asia lies in the energy security of India. The Indian interest in Central Asian energy sector demonstrates the desire of the former for a long-standing relationship with the region. A notable development in this direction took place in 2007, when similar to OPEC, an energy forum the SCO Energy Club was established in Moscow (De Haas 2010). This club is a significant communication forum between the producers and the buyers and it can be a vital agency for routing Central Asian energy to South Asia. The club can be a forum for engaging Iran to develop a comprehensive energy trade forum for pricing and transport of oil, gas and electricity. The geopolitical situation of South Asia prevents the full realisation of this potential. Moreover, the US sanctions on Iran prevents the extension of energy cooperation between South Asia and Iran, which is an important route for energy supplies in the resource exchange. China's strong financial investment in Central Asian energy sector and infrastructure influenced the initial orientation of energy trade. India was denied a share in Kashagan oil fields by Kazakhstan in 2013 and two years later when latter offered the Abai block, then India remained indolent. This had obvious influence from the growing footprints of the China National Petroleum Corporation (CNPC), who also bought Petro Kazakhstan in $2005^{9}$. Indian bid led by ONCG-Mittal Energy complained of the unfair treatment as they were not allowed to match the last minute alteration in bid by CNPC (Develi, Kaynak 2012: 211). Central Asian energy trade also has European component, as the resources are a point of geopolitical completion between Russia and the West. The Turkmen gas reserves are seen as a point of disenfranchisement of Central Asian republics whence they are transported to Europe bypassing Russia. Therefore, Russia has maintained a tight grip on Central Asian energy geopolitics to limit consequences of any European act (Tomberg 2012).

Russia has accepted China's support in maintaining collective balance in Central Asia that allows them to decide for the entire Eurasian region. The 'democratic' disruptions encouraged by the West in the form of colour revolutions are a common threat to both the powers. India represents entirely a different political set up with most diverse social-political structuring of national politics. Kazakhstan shows the ambition of great regional power, but the rest of the Central Asian states are more interested in diversification of economic and political relations that includes their preferences for South Asian linkages. The situation in Afghanistan and the India-Pak conflict prevents them access for the time being. This situation has forced most of the Central Asian re-

\footnotetext{
9 India rejects Kazakhstan's offer for Abai oil field. Retrieved from India rejects Kazakhstan's offer for Abai oil field. The Economic Times URL: https://m.economictimes.com/industry/energy/oil-gas/india-rejects-kazakhstans-offer-for-abaioil-field/articleshow/47705118.cms (accessed 21.12.2020)
} 
publics to look towards China or Russia for most of their economic interests. Central Asia can reach South Asia either through Afghanistan or Iran. The situation in Afghanistan depends on the success of negotiations between the US forces and Taliban. The US has not been able to disarm Taliban and there is little hope that agreements would allow a permanent peace between the Afghan government and Taliban without losing their respective power positions. Iran is the next probable hope for Central Asia who have already functional trade and transport arrangement with Iran. The movement of goods from Central Asia to Iran's Bander Abbas port and the Chabahar port is an important source of connectivity for these landlocked states. The US has put sanctions against both the schemes except for situations where it helps Afghanistan. Thus, Central Asia's reach to South Asia is also constrained by the US policies in the region.

India, Iran and Afghanistan concluded the Chabahar agreement for trade and transit in 2016. The pace could not pick up as India has special responsibility in its operationalisation, but India has little control over developments in Afghanistan and its Afghanistan policy has largely focussed on its security concerns emerging from Pakistan. Its interest in Afghanistan and Central Asia remain constrained by the possibilities of Islamist extremism getting foothold once the US forces decide to leave Afghanistan. India and Central Asia need to develop a comprehensive approach around Afghanistan that addresses a range of issues from trade, connectivity to regional security matters. This some later stage might take into account energy corridor being developed through either Pakistan or Iran. Russia’s presence in this scenario can be of high importance. Russia and Pakistan are developing a new generation of political relations in post-cold war period. Russia's growing presence in the Middle East allows it to have special role in matters of Afghanistan and South Asia as well. This can be of vital importance for Central Asian energy corridor, as India would need a neutral arbiter for its energy reliance through the Pakistani route, which is favoured by the TAPI partners.

The nuclear energy is one sector where Russia-India have growing partnership with Central Asian republics. Russia has been the supplier of technology and machinery, whereas Kazakhstan has been supplying nuclear fuel to India for its power plants. This segment is unique and remains largely unaffected by geographical or commercial influences. Russia has limited success in Central Asia trying to sell its Nuclear Power Plants (NPPs). Kazakhstan has apprehension in accepting offer due to its inheritance of Soviet legacy of nuclear program. However, Kazakhstan is equally keen to take advantage of its large uranium reserves that can link up with Russian technology. Both the countries established International Uranium Enrichment Centre in Angarsk in 2007 for supplies to nuclear plants world over. India is a big customer of Rosatom, who already provides operational logistics to Kudankulam, Tamilnadu nuclear plants. Kazakhstan, Russia and India are already enjoying a tango in nuclear energy trade and there is proposal for further expansion of units ${ }^{10}$. India purchased from Kazakh-

\footnotetext{
${ }^{10}$ Pannier B. 2019. Putin Offers Russian Help To Build Kazakh Nuclear Plant. RadioFreeEurope/RadioLiberty. URL: https:// www.rferl.org/a/kazakhstan-putin-offers-russian-nuclear-plant-help/29865177.html (accessed 21.12.2020)
} 
stan 2100 metric tonnes of uranium between 2010-2014, and another agreement was signed in 2015 to supply 5000 metric tonnes until 2019. Russia, India and Kazakhstan can use their experience to expand the nuclear energy industry to other countries. Nuclear energy production has an advantage of carbon emission free, which makes it competitive to hydrocarbon energy industry. Russia and India have come together to build Bangladesh's first nuclear power plant. Russia is expanding its footprint in Africa and Middle East, where the three countries can develop long-standing partnership for energy trade ${ }^{11}$. India signed agreement in January 2019 for uranium ore from Uzbekistan. This shows that most of the Central Asian republics are on board with India's energy security paradigm. The CASA-1000 is not dealt here as it is not India specific and this project depends just like TAPI on access through Pakistan. Those Central Asian energy sources, which are competitive only when routed via Pakistan, are off the block for now as India-Pakistan remain in conflict due to low-intensity warfare in Kashmir. Pakistan is reaching out to Central Asia via Afghanistan. This is conditioned by the fact that Central Asia and Pakistan are both converging on China's Belt and Road Strategy. Pakistan tries to match New Delhi's influence by augmenting geopolitical levers however it is in the interest of Pakistan to curb the extremist tendencies emerging from its soil as it will ultimately hurt latter's relations with Central Asian states (Chulkov 2020).

\section{India's Energy Security in Global Perspective}

India has also emerged as a leading exporter of petroleum products. India's more than one tenth of exports fall under this category. Indian refining capacity is the fourth largest after the US, China and Russia. Its refineries at Koyali, Kochi, Mangalore, Panipat, Paradip, Mumbai, Bhatinda and Manali (TN) have capacities over 10 million metric tonne per annum (MMTPA). The biggest refineries are in private sector at Jamnagar by Reliance Industries having capacity of 68 MMTPA and Russia's Rosneft-purchased Essar Oil also in Gujrat (Vadinar) with capacity of 20 MMTPA. The coastal refineries are also the major exporters of refined products. The Vadinar refinery is the second largest unit in private sector and has wide range of product diversification in refined outputs. The Essar Oil Company was purchased by a consortium led by the Rosneft in 2017 and renamed it as Nayara Energy limited. This consortium has more than 7,000 retail fuel outlets in India to meet the domestic demand ${ }^{12}$ (Abdi 2020). More than half of India's petroleum exports consists of HS 271019 class of products such as aviation kerosene, high speed diesel, light diesel oil, textile oil, gear oil, lubricants, hydraulic oil, transformer and circuit breaker oil, and oils needed by cosmetic industry. India also

\footnotetext{
${ }^{11}$ Abbasova V. 2020.126). Indian Envoy To Russia Says Countries Could Build Nuclear Power Plants In Africa \& Middle East. Caspian News. URL: https://caspiannews.com/news-detail/indian-envoy-to-russia-says-countries-could-build-nuclearpower-plants-in-africa-middle-east-2020-1-25-24/ (accessed 21.12.2020)

12 Abdi B. 2020. Nayara Energy to invest Rs 6,100 crore to set-up 450 KTPA polypropylene plant at Vadinar. Energy World. URL: https://energy.economictimes.indiatimes.com/news/oil-and-gas/nayara-energy-to-invest-rs-6100-crore-to-set-up450-ktpa-polypropylene-plant-at-vadinar/74676064 (accessed 21.12.2020)
} 
leads in exporting aviation spirit. India's major clients are Netherlands and Singapore. However, India's major share of exports are located around Indian Ocean Rim (IOR) countries, which explains India's strategic location for catering the needs of IOR market. India exports in Africa to Kenya, Mauritius, Mozambique, South Africa, Egypt, Angola, and Tanzania. India's Asian importers are Bangladesh, China, Israel, Japan, Jordan, Malaysia, Nepal, Sri Lanka, Turkey, South Korea, UAE and Saudi Arabia. India's European partners are UK, France, Belgium, Gibraltar and Malta. India has been exporting to Australia also. It is interesting to note that even the oil producer countries are also importers of the refined products from India, which indicates the transport economics between the raw material location and consumer location are fully optimised to utilise the movement of carriers.

Russia has become a major player in oil markets with its increased presence in the Middle East. Russia's energy geopolitics is an important policy vector that needs to be understood for any meaningful connection between Russia and India in this sector. Russia has been deploying energy diplomacy aggressively to counter the US hegemony in Europe and at the same time, its relations with Middle East countries have become much comprehensive that has allowed it to influence the oil and gas production scenario in the Middle East as well. India does not afford that kind of ambition with its expanding energy exports, as India is not a significant crude oil producer country. India's refining capacity has a role for Russia's production geopolitics. If the two match in proper manner, then Russia and India can jointly manage the global energy situation to their advantage. This is also relevant given the fact that India's geographical location is ideally suited to cater to Asian and African markets, whereas Russia would be holding on Europe for a long-time to manage the US pressure. Russia has both crude oil and natural gas reserves that play important role in its energy geopolitics. However, they are disparate in nature of influence. Russia exported crude and refined oil products worth more than 200 billon USD in 2018.

Its gas exports were a little more than 6 billion USD in 2018, which included liquefied forms too. Thus, it is clear that Russia has prime focus on oil exports. Its major oil export destinations are Netherlands, China, South Korea, Poland and Italy. Japan has been an invariable beneficiary of the Russian gas exports. It has received almost half of the total Russian gas exports as per the UN Comtrade data for period 2009 to 2018. South Korea is another important recipient of Russian gas. This share is bound to alter as Russia has started exporting gas to China via its mega-project known as the Power of Siberia. France and Poland are the major European customers of Russian gas followed by Netherlands, Belarus and Ukraine. Russia's distribution of oil and gas exports demonstrates geopolitical thought process. It has disallowed resource competition among neighbouring recipients. This observation has relevance while factoring Central Asia into Russia-India trade relations. Since Russia has priority towards Europe in oil exports, it also means that India is more inclined to buy oil from Middle East. The Central Asian gas fits into this picture where Russia can play an important role by exploring this segment for export to India. This would not hurt its geopolitical 
priorities in Europe and allow developing the South and Central Asian policy architecture in terms of energy geopolitics. India stands to gain with Russian involvement in Central Asian gas exports. It can be a reliable guarantor through Iran and Pakistan, which are the only two possible corridors for the Central Asia exports. India-Iran energy relations also have an important bearing on exploration of these possibilities. Iran is not only an important supplier of crude oil to India, but also a strategic facilitator for accessing Afghanistan and Central Asia. The US sanctions against Iran has affected energy relations between the two countries. The US pressure in Persian Gulf has affected India's shipping business adversely. The US-led West has adverse relations with Iran, which is detrimental to India-Iran energy relations. It was visible in the August 2019 incident when the Indian captain-led Iranian ship was abducted by the British marines in total violation of international law of seas ${ }^{13}$. India was also forced to stop buying crude from Iran and Venezuela in May 2019 after the waiver deadline expired ${ }^{14}$. The oil used to fund for most of the Iranian imports from India under the rupee-rial agreement. Iran has also been dissatisfied with India buckling under the pressure from the US.

India and Iran opened a new chapter of energy cooperation in 2005 when the two countries signed a long-term agreement for shipping LNG from the gigantic Iranian South Pars field. The ONGC was active in Farzad B gas field discovery, which could have expanded the Indian footprint in Iranian gas exploration in successive years. However, the US forced India to abandon all forms of energy trade with Iran after it left the Iranian Nuclear deal. The Trump administration obliterated the US's Iran policy by withdrawing from the Obama administration signed Joint Comprehensive Plan of Action (JCPOA) that hurt Indian interests in a significant way. India encouraged by this agreement had requested the Iranian government in 2016 to create a Chabahar SEZ for Indian petro-chemical industries that would include an LNG terminal and fertilizer plants for Indian markets ${ }^{15}$. Russia can be an important partner in Iranian energy sector as it can link the Central Asian gas network with the Gulf gas supplies. Russia has been consolidating its gas supplies in the Persian Gulf by collaborating with Qatar. Russia is offering Qatari gas to Pakistan, which would be an extended network for Iran, Saudi Arabia and other to join for transportation of Middle East gas via seabed pipelines to South Asia. Russia's experience both in terms of technology and pipeline geopolitics would come handy in exploring the successful connectivity across Middle East and South Asia. Russia's has gained significant leverage with OPEC due to its large

\footnotetext{
${ }^{13}$ Gibraltar releases Iranian tanker, Indian crew despite US claim on vessel. Business Standard India. URL: https://www. business-standard.com/topic/iranian-oil-tanker (accessed 21.12.2020)

14 US deadline ends, India stops purchasing Iranian oil. The Economic Times. URL: https://economictimes.indiatimes.com/ industry/energy/oil-gas/us-deadline-ends-india-stops-purchasing-iranian-oil/articleshow/69475495.cms?from=mdr (accessed 21.12.2020)

${ }^{15}$ India keen on setting up LNG terminal at Iranian port. The Economic Times. URL: https://economictimes.indiatimes.com/ industry/energy/oil-gas/india-keen-on-setting-up-Ing-terminal-at-iranian-port/articleshow/52078550.cms (accessed 21.12.2020)
} 
growing relations with Saudi Arabia. This has allowed Russia to steer the crude prices suitable to its economic interests in consumer nations. India stands benefitted with Russia's growing clout in the OPEC. The OPEC Secretary General emphasized the role of OPEC-India dialogue in promoting joint projects between India and OPEC at the India Energy Forum meeting held in October 2017. Russia can provide technological stimulus to these initiatives both at the point of production and to the point of consumption as well.

Russia-Pakistan energy cooperation is a significant dimension for its grand South Asian gas network strategy. Russia holds significant stakes in gas deposits of Bahrain and Qatar and its premier company Gazprom Gas Company signed 10-billion-dollar agreement with Pakistani state agency Inter-State Gas Systems (ISGS) for supplying the Gulf gas at the rate of 500 million cubic feet of gas per day ${ }^{16}$. This agreement is linked with another agreement signed by Moscow and Islamabad to build a NorthSouth pipeline connecting Karachi and Lahore costing around two billion dollars. The Eurasian Pipeline Consortium (EPC) and Federal State Unitary Enterprise (FUSE) are the two Russian companies engaged in construction of this project ${ }^{17}$ (Yousufzai 2020). Russia plans to invest around 14 billion dollars in Pakistan for the expansion of its gas network in the region ${ }^{18}$. Russia and Pakistan have entered into a number of other agreements such as in July 2017, Gazprom and the Oil and Gas development company of Pakistan signed a joint venture agreement to assist in research and development. In 2018, the Russian and Pakistani energy ministries have agreed to cooperate on offshore pipeline projects. According to the project, gas extracted from Iran's fields can be transported via Pakistan ${ }^{19}$.

Russia's energy drive in South Asia would remain bi-partisan for some time, as there is very little hope as of today for linking India and Pakistan energy network. This would have given great mileage for salvaging the South Asian energy situation as Afghanistan and Central Asia would have benefitted from such a transit opportunity between the two regions. There are great power relations that are also present in the region that need to be addressed. The US's dream of carving an energy corridor across Afghanistan as New Silk road remained largely defeated due to its tangled relations with Taliban and Pakistan. The US lost its foothold in Central Asia due to heightened insecurity from colour revolutions. The US secretary of the State in his most brazen display of China bashing went on propaganda tour to Central Asian republics in February 2020 almost warning them to desist from inviting Chinese Huawei for 5G in-

\footnotetext{
${ }^{16}$ Khan I. 2019. Pakistan signs $\$ 10$ bn gas pipeline agreement with Russia. Retrieved from Pakistan signs $\$ 10$ bn gas pipeline agreement with Russia. The News. URL: https://www.thenews.com.pk/print/428722-pakistan-signs-10-bn-gaspipeline-agreement-with-russia (accessed 21.12.2020)

17 Yousufzai F. 2020. Pakistan approves structure for \$2b North-South Gas Pipeline. The Nation. URL: https://nation.com. pk/22-Jan-2020/pakistan-approves-structure-for-dollar-2b-north-south-gas-pipeline (accessed 21.12.2020)

${ }^{18}$ Russia plans to invest \$14 billion in Pakistan's energy sector. Energy World. URL: https://energy.economictimes.indiatimes. com/news/oil-and-gas/russia-plans-to-invest-14-billion-in-pakistans-energy-sector/67883013(accessed 21.12.2020)

${ }^{19}$ Narkevsky D. 2019. Neftegazovye nadezhdy Pakistana. Russian Council. URL: https://russiancouncil.ru/analytics-andcomments/analytics/neftegazovye-nadezhdy-pakistana/ (accessed 21.12.2020)
} 
frastructure. India remains sceptic as the Chinese infrastructure companies with their willingness to share technology and expertise at reasonable price are finding it difficult to do business under the US-China trade standoff. Russia and India too enjoy similar understanding. Russian companies have been willing to share their technology and expertise in nuclear energy production and LNG transportation with Indian counterparts. India has been able to secure licence from Russian companies in number of production lines, which it had been unable to secure from the Western 'democracies'. The growing trade war between the US and China would make transfer of technology increasingly difficult for third parties. India has benefited from trade openness where technology arrived for non-conventional sources such as solar, wind and nuclear energy. The refinery business that has expanded making it the fourth largest refining capacity nation shows rise in India's credibility with greater access to investments and technology. The geographical barriers between India and Central Asia are manageable only with newer technological breakthroughs. The LNG tankers technology developed by Hyundai and Daewoo enable maintaining of the gas temperature at minus 165 degree Celsius thereby allowing transport of LNG across the globe ${ }^{20}$.

The globalisation of production chains has its impact on resource marketability. Most of the products in our daily lives are an assembly of components supplied by different countries. Energy fuels too have this kind of scenario. The Middle East countries are a big supplier of crude but the refineries have taken away the business to newer destinations and the intermediate countries are now having an important share deciding the production of crude and supply routes. Russia is a big producer of crude oil and natural gas, whereas India can hardly meet its domestic requirements, yet both are in the business of selling petroleum products to rest of the world. This augurs a cooperation between Russia and India on a supply chain so that India can produce the petroleum distillates and then they are exported to suited destinations. Russia's Rosneft has made a beginning by making a very promising start with Nayara refinery in Gujrat. Russia and India can work on coastal refinery such as in Kochhi or Mangalore that can provide products to Africa, Europe and the Southeast Asian countries. India and Russia also have an opportunity to view simultaneous expansion of oil and defence ties. India and Russia can do each other a great of favour if they do not limit their priorities to defence cooperation where Russia has been keen to provide S-400 defence architecture and modern Kamov helicopters coveted by Indian defence forces and in return India can partake its export earnings to buy Russian weapons. India's public sector has a growing presence in Russian energy resources exploration and production. The defence and energy can be synergised into a giant trans-continental territorial production complex, something that both Russia and India know since their earliest days of planned regional development.

\footnotetext{
20 Paris C. 2019. Shipping Companies Banking on Gas Carriers as LNG Demand Grows. Wall Street Journal. URL: https:// www.wsj.com/articles/shipping-companies-banking-on-gas-carriers-as-Ing-demand-grows-11552555800 (accessed 21.12.2020)
} 
This brings into the question of locating Central Asia in the Russia-India energy trade matrix. One might well argue that Russia-India have vast opportunity to expand energy ties, so how prudent it would be to visualise the Central Asian energy resources as a part of their trade matrix. The geopolitical scenario of South Asia augurs that Russia and India get Central Asian countries into loop so as the regional politics is not disturbed by the great power geopolitics. The prioritizing of energy minerals is desirable as they are the biggest trading asset of the Central Asian countries. Therefore, it is wise that Russia and India allow a share of their trade potential harnessed by the Central Asian partners. This is also the most sustainable class of trade relations, as these constitute the biggest component of their exports too. The geopolitical rationale for economic argument might appear unsound but that is how the situation in Afghanistan unfolded after the withdrawal of the Soviet forces. The first thing that the US and Benazir Bhutto government in Pakistan did was to declare their intention to bring in the Central Asian energy resources to the South Asian markets. Therefore, the historic conditions are the best guiding path to make the most out of business opportunity. Russia and India can utilise their capacity to reinvent that energy trade in a more balanced format in present conditions. The Novorossiysk agreement of 2020 can be a harbinger to export Caspian oil and gas to India.

These geopolitical designs could have been deliberated further had there been not an unprecedented situation of pandemic from Covid-19. It has thrown all geopolitical assessment off the gear as the demand for energy resources plummeted world over. The producers are not able to decide what to do with oil and gas outpouring. The energy trade is under dramatic change due to Covid-19 pandemic as it has wiped off the demand for energy fuels due to worldwide halting of economic activities. The situation could be imagined with the fact that the US crude oil prices went negative at minus 40 USD in April 2020 for the first time in history, meaning that the producers were willing to pay for lifting the crude physically ${ }^{21}$. Russia appears to have endured the oil shock as the price largely affected the WTI crude oil, whereas it primarily exports Urals, which is tagged with the Brent crude oil. However, in terms of revenue from oil one can see a two-fold drop in prices and a 20-25\% reduction in the volume of Russian exports of oil, gas and coal. This would be equivalent to a reduction of $60 \%$ in export earnings. The current shocks to the Russian energy sector appear to be temporary against the background of long-term interests in the energy trade. It is also possible that new technology paradigm might appear as a result of Covid-19 manifesting decarbonisation, decentralization and digitisation giving an additional impetus to the energy diversification, especially in the European market, which is the major one for Russia ${ }^{22}$.

\footnotetext{
${ }^{21}$ Cordell J. 2020. Explainer: What Happened to Oil Prices and What Does it Mean for Russia? Retrieved from Explainer: What Happened to Oil Prices and What Does it Mean for Russia? The Moscow Times. URL: https://www.themoscowtimes. com/2020/04/21/explainer-what-happened-to-wti-oil-prices-and-what-does-it-mean-for-russia-a70055

${ }^{22}$ Mitrova T. 2020. Korona-neftyanoi obval. Chto zhdet rossiiskuyu energetiku posle epidemii. Chto zhdet rossiiskuyu energetiku posle epidemii? Carnegie. (In Russian). URL: https://carnegie.ru/commentary/81790 (accessed 21.12.2020)
} 
The Indian energy scenario can gain more attention in wake of such transition. India's reliance on hydrocarbons as a primary source shall continue to remain for coming decades. It is going to play major role in expansion of economic activities in secondary towns and rural areas where most of the demand for fuel is going to shift. It is only well suited for Russia and India to look for a long-term partnership that can address the demand-supply match making in a geopolitically fragile environment. This cooperation certainly cannot bypass the technological challenge due to new imperatives of environment friendly consumption. The Russian oil and gas sector can take the lead by restructuring the industry and integrating hydrocarbons into the green agenda. A special focus can be towards decarbonizing oil and gas, which is a complex, expensive process that requires new technologies and competencies. The Central Asian countries have been quite conscious too of the impact of energy fuels on their fragile environment and they can take up multi-lateral partnership for better quality of products for export.

The most significant result of the trilateral energy trade would be the growing incentive to balance the geopolitical situation in Afghanistan. Afghanistan is a wartorn country and the politically fragile environment that is in constant need of economic sustenance. The energy could be the most fundamental and lasting measure to transform the conflict in Afghanistan towards reconciliation. The supply of electricity and crude distillates from Central Asian countries has already demonstrated positive impact in the countryside of Afghanistan. The warlords also understand the role of energy in influencing the lives of the common people. This enabler of Central Asia to intervene effectively in Afghanistan is dialectical process that would allow Central Asia to be more confident in its engagement with South Asia. Therefore, Russia-India energy trade relations are not confined to oil and gas, but they can be perceived for far reaching impact in the Greater Central Asian region. Countering terrorism and maintaining vital lines energy supplies from the region are part of a complex set of problems that would be solved over a period. The stability and peace in Afghanistan and Central Asia would allow Russia to develop relations with Pakistan on much better terms. They can do away with the bi-partisan necessity of dealing with Pakistan and India at different levels. It would give them an opportunity to connect with much larger good of the South Asian peoples. Russia and Central Asia would be highly benefitted with the decrease in confrontation between India and Pakistan. These positions can be visualised with increased benefit to Central Asian states via Russia-India trading linkages that can begin with energy but not limiting themselves to this only but getting more diversification with newer production chains. 


\section{About the authors:}

Ambrish Dhaka - Associate Professor, School of International Studies, Jawaharlal Nehru University. 110067 New Mehrauli Road, Munirka, New Delhi, India. Email: ambijat@gmail.com

Marina Dmitrieva - Assistant Professor, The International Relations Department, School of Regional and International Studies, Far Eastern Federal University. 690922, Primorsky Territory, Vladivostok, Russky Island, Ajax, 10. Email: dmitrieva.mo@dvfu.ru

\section{Conflict of interests:}

The authors declare absence of conflict of interests.

\section{Роль Центральной Азии в российско-индийском сотрудничестве в области энергетики}

\section{А. Дакка, М. Дмитриева}

DOI 10.24833/2071-8160-2020-6-75-208-227

Университет Джавахарлала Неру, Индия

Дальневосточный федеральный университет, Россия

Россия стала крупным игроком на энергетическом рынке. Участие в решении сирийского кризиса укрепило позиции России на Ближнем Востоке, что отразилось на глобальном нефтяном рынке. Индия растёт темпами выше 5\% в год, её энергетические потребности существенны. У Индии и России особые отношения, обусловленные давними культурными и политическими связями, они положительно влияют на энергетическую безопасность Индии. Центральноазиатские республики имеют особое значение для России и Индии с точки зрения стратегической безопасности в регионе Южной и Центральной Азии. Оба государства связаны с этим регионом и защищают его от угроз религиозного экстремизма и терроризма, усугубляющихся проблемой незаконной торговли наркотиками и оружием. В Центральной Азии сосредоточены одни из крупнейших в мире запасов природного газа, который успешно экспортируются по трубопроводам. Этот подход невозможен в Южной Азии из-за ситуации в Афганистане. Поэтому Россия остаётся важным маршрутом доступа к энергоресурсам из Евразии и, в частности, из Центральной Азии. Индия также в значительной степени связана с морской торговлей энергоресурсами со странами Африки и Латинской Америки, что повышает альтернативные издержки доступа к энергоресурсам Центральной Азии. В статье подчёркивается значение энергетической торговли между Россией, Индией и странами Центральной Азии, которая могла бы способствовать геополитической стабильности во всём регионе.

Ключевые слова: Россия, Индия, торговля энергоресурсами, Центральная Азия, Афганистан, Южная Азия, геополитика, международное сотрудничество, стратегическое партнёрство 


\section{Oб авторах:}

Амбриш Дакка - доцент Школы международных исследований Университета Джавахарлала Неру. 110067 New Mehrauli Road, Munirka, New Delhi, Индия.

E-mail:ambijat@gmail.com

Марина Олеговна Дмитриева - старший преподаватель кафедры международных отношений Школы региональных и международных исследований Дальневосточного федерального университета. 690922, Приморский край, г. Владивосток, о. Русский, п. Аякс, 10. Россия. Электронная почта: dmitrieva.mo@dvfu.ru

\section{Конфликт интересов:}

Авторы заявляют об отсутствии конфликта интересов.

\section{References:}

Belyi A. 2003. New Dimensions of Energy Security of the Enlarging EU and Their Impact on Relations with Russia. European Integration. 25(4).351-369. DOI: 10.1080/0703633032000163193

De Haas M. 2010. Russia's Foreign Security Policy in the 21st Century: Putin, Medvedev and Beyond. Taylor \& Francis. DOI: 10.4324/9780203854402

Develi A., Kaynak S. 2012. Energy Economics. Peter Lang GmbH, Internationaler Verlag der Wissenschaften.

Iazmuradov A. 2006. Greater South Asia-America's New Regional Approach to Central and South Asia: How it is Developing And What Prompted it. Central Asia and the Caucasus. 4(40). P. 79-90.

Fredholm M. 2012. The Shanghai Cooperation Organization and Eurasian Geopolitics: New Directions, Perspectives, and Challenges. M. Fredholm (Ed.). NIAS Press.

Sutyrin S., Trofimenko O.Y., Koval A. 2019. Russian Trade Policy: Achievements, Challenges and Prospects. Taylor \& Francis.

Tomberg I. 2012. Central Asian gas in the changing geopolitical context. Central Asia and the Caucasus. 13(1). P. 7-20.

Tolipov F. 2015. Micro-Geopolitical Semiotics of Central Asia: "crossroads" and "bridges". Central Asia and the Caucasus. №16. P. 35-42

Akarashov I.S. 2017. Rossiya - Indiya: neobkhodimo povyshat' uroven' doveriya. [Russia India: it is Necessary to Increase the Level of Trust]. Bulletin of the peoples 'friendship University of Russia. Series: universal history. 9(3). P. 222-233. DOI: 10.22363 / 2312-8127-2017-9-3-222233 (In Russian)

Akarashov I. S. 2018. Rossiya - Indiya: novye gorizonty strategicheskogo al'yansa. [Russia - India: New Horizons of the Strategic Alliance]. Bulletin of the peoples 'friendship University of Russia. Series: International relations. 18(1). P. 148-161. DOI: 10.22363/2313-0660-2018-18-1148-161 (In Russian)

Garusova L. N., Zhurbey E.V. 2018. Strategicheskoe partnerstvo Indii i SShA v XXI veke: regional'nyi kontekst [Strategic Partnership of India and the United States in the 21st Century: Regional Context]. Transbaikal State University Journal. 24(10). 65-75. DOI: 10.21209/22279245201824106575 (In Russian)

Guchmazova A. P. 2017. Sostoyanie i perspektivy rossiisko-indiiskogo torgovo-investitsionnogo sotrudnichestva [State and Prospects of Russian-Indian Trade and Investment Cooperation]. Skiff. Questions of student science. 8(8). P. 168-174. (In Russian) 
Konovalova Yu.A. 2017. Russia - India: osobennosty vzaimnoy torgovli na sovremennom etape [Russia - India: Features of Mutual Trade at the Present Stage]. Bulletin of the peoples ' friendship University of Russia. Series: Economics. 25(3). P. 295-308. DOI: 10.22363/2313-23292017-25-3-295-308 (In Russian)

Luzianin S. 2007. Kitaiskie «korni» i rossiiskie «vetvi» v Tsentral'noi Azii (k voprosu o sootnoshenii politiki KNR i RF v regione) [Chinese "Roots" and Russian "Branches" in Central Asia (On the Correlation of Chinese and Russian Policy in the Region)]. Central Asia and the Caucasus. 3(51). P. 99-106. (In Russian)

Minina T.I., Glekov E.Ya. 2019. Torgovaya integratsiya Rossii i Indii [Trade Integration of Russia and India]. Chronosequence. 2(15). P. 125-129. (In Russian)

Khusainova G.T. 2015. Uchastie Bashkortostana v razvitii svyazei Rossii i Indii [Participation of Bashkortostan in the Development of Relations between Russia and India]. Problems of Oriental studies. 2(68). P. 53-59. (In Russian)

Zakharov A.I. 2016. Strategicheskoe partnerstvo SShA i Indii: vyzovy dlya Rossii [USIndia Strategic Partnership: Challenges for Russia]. Power. 24(8). P. 195-198. (In Russian)

\section{Список литературы на русском языке.}

Акарашов И.С. 2017. Россия - Индия: необходимо повышать уровень доверия. Вестник Российского университета дружбы народов. Серия: Всеобщая история. 9(3). C. 222-233. DOI: 10.22363/2312-8127-2017-9-3-222-233

Акарашов И.С. 2018. Россия - Индия: новые горизонты стратегического альянса. Вестник Российского университета дружбы народов. Серия: Международные отночения. 18(1). C. 148-161. DOI: 10.22363/2313-0660-2018-18-1-148-161

Гарусова Л.Н., Журбей Е.В. Стратегическое партнёрство Индии и США в XXI веке: региональный контекст. Вестник Забайкальского государственного университета. 24(10). C. 65-75. DOI: 10.21209/22279245201824106575

Гучмазова А.П. 2017. Состояние и перспективы российско-индийского торгово-инвестиционного сотрудничества. Скиф. Вопросы студенческой науки. 8(8). С. 168-174.

Коновалова Ю.А. 2017. Россия - Индия: особенности взаимной торговли на современном этапе. Вестник Российского университета дружбы народов. Серия: Экономика. 25(3). C.295-308. DOI: 10.22363/2313-2329-2017-25-3-295-308

Лузянин С. 2007. Китайские «корни» и российские «ветви» в Центральной Азии (к вопросу о соотношении политики КНР и РФ в регионе). Центральная Азия и Кавказ. 3(51). C. 99-106.

Минина Т.И., Глеков Э.Я. 2019. Торговая интеграция России и Индии. Хроноэкономика. 2(15). 125-129.

Хусаинова Г.Т. 2015. Участие Башкортостана в развитии связей России и Индии. Проблемы востоковедения. 2(68). С. 53-59.

Захаров А.И. 2016. Стратегическое партнёрство США и Индии: вызовы для России. Власть. 24(8). С. 195-198. 